\title{
Enhancing Student Engagement In A Multidisciplinary, First-Year Experience Course
}

\author{
Michael Stebleton, University of Minnesota-Twin Cities, USA \\ Murray Jensen, University of Minnesota-Twin Cities, USA \\ Gary Peter, University of Minnesota-Twin Cities, USA
}

\begin{abstract}
Three faculty members from three different professional disciplines outline strategies to engage first-year students in a team-taught, multidisciplinary first-year experience course. The theme of the discussed section is titled food for thought... and action. Assignments are grounded in theories of cooperative and experiential learning. Tentative outcomes and students' reactions are shared. Practical suggestions are included for educators who wish to implement comparable initiatives at their respective institutions.
\end{abstract}

Keywords: Student Engagement; First-Year Experience; Multidisciplinary Instruction; Faculty; Cooperative Learning; Experiential Learning

\section{INTRODUCTION}

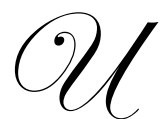

niversities and colleges of all sizes continue to explore innovative and effective strategies to engage and retain students, especially first-year students (Kuh, Kinzie, Schuh, \& Whitt, 2005). Extensive research on student retention issues clearly indicates that academic and social engagement initiatives during the first semester leads to higher first-to-second year retention rates as well as ongoing persistence towards graduation (Kuh, 2009; Pascarella \& Terenzini, 2005; Tinto, 1993). The success rates of first-year initiatives can be enhanced by incorporating high impact educational practices and other educationally purposeful activities that promote engagement (Hu \& Kuh, 2002; Kuh, 2008). The purpose of this article is to describe how three faculty members from different disciplines integrated several of these practices into a multidisciplinary, first-year experience (FYE) course that examined food-related issues. The purpose of this article is to describe how three faculty members from different disciplines integrated several of these practices into a multidisciplinary, first-year experience (FYE) course that examined food-related issues.

\section{DEFINITIONS AND BACKGROUND}

Engagement is an agreement between what the student does to reach success and what the institution does to facilitate that process on behalf of the student. When studying college student engagement issues, scholars typically explore both academic and social engagement measures (Harper \& Quaye, 2009; Wolf-Wendel, Ward, \& Kinzie, 2009). Academic engagement usually refers to student investment in the classroom experience, interaction with faculty, time spent studying, and academic achievement. Social engagement refers to students' social investment in the collegiate experience. These are activities that occur outside the classroom (e.g., meeting new friends, participating in student groups or learning activities, and time spent in online social networking activities). Persistence refers to student perseverance towards targeted goals, mainly graduation.

Much of the scholarly research conducted on college student engagement issues concentrates on understanding the best institutional practices that increase the likelihood of engagement on behalf of students, and ultimately, contribute to college success (Kinzie, Gonyea, Kuh, Umbach, Blaich, \& Korkmaz, 2007; Kuh, 2008; 
Lardner \& Malnarich, 2008). Specific examples of high impact educational practices include learning communities, first-year seminars, writing intensive courses, common intellectual experiences (e.g., shared book), internships, service learning opportunities, study abroad options, and other integrative and intentional learning activities with targeted outcomes. Many of these strategies are purposively integrated into first-year experience programs, as is the case with our initiative at the University of Minnesota-Twin Cities.

The University of Minnesota-Twin Cities is a large, public four-year research university located in Minneapolis-St. Paul, Minnesota, enrolling approximately 30,000 undergraduate students. The College of Education and Human Development (CEHD) is home to more than 5,200 students with 475-500 first-year students entering each fall. As a strategy to promote student engagement and persistence, the college embarked on a required comprehensive first-year inquiry (FYI) program, starting in the fall semester 2008.

\section{THE COURSE}

All entering CEHD undergraduate students enroll in a four-credit course, Multidisciplinary Ways of Knowing. The course is team taught by 18 faculty members from diverse disciplines (i.e., three faculty assigned to each of the six sections). Each section consists of approximately 75-80 students and has a theme determined by the faculty. The format includes two components: (a) a weekly large group meeting with the entire class and all three faculty members and (b) a weekly small group meeting (e.g., 25 students, one instructor). The authors of this article -- a social scientist, a lawyer, and a biologist -- designed a section of the course around the theme of food.

The section titled Food for Thought... and Action, takes a multidisciplinary approach to food, thus reflecting the different expertise and backgrounds of the instructors. The course examines such issues as fast food and its health, social, and cultural implications; food regulation and safety; food production and nutrition; food and the media; and food and relationships. Texts for the course have included Michael Pollan's In Defense of Food and Fast Food Nation by Eric Schlosser, as well as both novels and memoirs containing food-related themes. The course also draws heavily from current events related to food, and thus articles from The New York Times and other popular sources are also assigned. Because the course is designated as writing intensive, students are required to complete 10-15 pages of polished writing and revise one assignment (the Individual Capstone Paper, discussed in more detail below) following feedback from their small group instructor in an individual conference. Students also receive instruction in research methods and practices, including locating both scholarly and secondary sources.

\section{FRAMING THE CHALLENGE}

One of the main questions that challenged us throughout the experience was, "How can three faculty members from three different disciplines engage a group of 75-80 students several hours per week for an entire semester?" We asked our students for help. At regular intervals, students in all sections provided feedback about the progress of the course in the form of a qualitative critical incident questionnaire (Brookfield, 1995). These openended online journal prompts (often only 2-4 questions) were administered 3-5 times over the semester, usually at key transition points in the semester including mid-term. An example of a question from the critical incident questionnaire is: At what point in the class are you most engaged?

The majority of students indicated that they felt most engaged during the small discussion session and less engaged during the large lecture. This feedback prompted changes in pedagogy to be made during those first few weeks of the semester (e.g., less lecturing and more interactive exercises in the large group section). Student feedback improved after changes were made. Initially, all faculty members in the college FYE program constructed the curriculum based on high impact educational practices, including a common intellectual experience (e.g., shared book), a writing intensive requirement, capstone projects, and collaborative learning activities such as a group final project. The intent of these activities was to produce a high quality FYE program emphasizing critical inquiry, information literacy, frequent writing opportunities, and group work. The challenge was to find innovative ways to integrate these practices into the small and large group settings. Prior to the initial offering of the course, we discussed targeted learning outcomes as well as the theoretical paradigms that would guide our work with first-year students. 


\section{COOPERATIVE LEARNING AND EXPERIENTIAL LEARNING THEORETICAL FRAMEWORKS}

Although a comprehensive review of cooperative learning theory is beyond the scope of this article, it is worth noting that these models serve as a foundation for much of the work we do in the first-year inquiry course. At the center of cooperative learning is the premise that knowledge and learning are largely social endeavors; students need to be activity engaged in the construction of their own knowledge, and must use that knowledge for it to have utility. Cooperative learning is often confused with simple group work. Two major differences exist between simple group work and true cooperative groups; positive interdependence between group members and a sense of individual accountability are evident in cooperative learning (Johnson, Johnson, \& Holubec, 1998). Positive interdependence is the notion that the success of the individual is directly linked to the success of the group (i.e., sink or swim together). Individual accountability is a group dynamic where each person is ultimately responsible for their own knowledge. When designing any cooperative group activity, these two components must be present, or scenarios of student slacking occur, with group activities devolving into socializing, texting, and other nonproductive activities that detract from student learning.

To enhance this educational experience for students, instructors can meet the conditions of cooperative learning by integrating strategies such as assigning each student to a specific role within the group (e.g., note taker, question clarifier), requiring an individual accountability report completed by each group member at the end of a project, and by giving individual exams after the completion of a group project. Over 100 years of research and practice in cooperative group learning has resulted in articles, books, and websites with proven methods for forming and maintaining effective cooperative groups. The faculty of the first-year inquiry course in the college intentionally integrated cooperative learning theory and strategies throughout the curriculum.

A second theoretical paradigm that guides the first-year experience is experiential learning theory and practice. Experiential learning theory is based on the premise that students learn best by doing, or engaging in activity centered on key concepts or student learning outcomes (Kolb, 1984). Kolb argued that there are numerous learning styles, and that each student has certain preferences (e.g., converging, diverging, assimilating, and accommodating). Students frequently learn best by testing out hypotheses and then reflecting on the outcomes. Often, the most impactful learning can occur outside of the classroom through intentional experiential learning activities that make use of community resources. In our section of the FYE, we required students to apply concepts of sociology to a visit to a local farmers' market in the Twin Cities. This project is described in the next section.

\section{ENGAGEMENT STRATEGIES INSIDE (AND OUTSIDE) THE CLASSROOM}

There are five main strategies used to enhance academic and social student engagement in the small and large class settings of the first-year inquiry course. These specific projects include:

\section{Farmers' Market Visit}

Early in the fall semester, students travel off-campus on a Saturday morning to visit a farmers' market in the area. The project accomplishes three goals: 1) engages students in an experiential learning opportunity; 2) requires students to apply participant observation skills in a community setting; 3 ) asks students to critically examine if farmers' markets can serve as effective third places (Oldenburg, 1999; Tiemann, 2008). Students submit a reaction paper reflecting on their experience. For many students, this is their first encounter with a farmers' market as well as public transportation to a downtown locale in an urban setting.

\section{Simulated Town Hall Meeting}

The town hall forum occurs during the unit on food zoning politics and the power of food advertising. One of the professors shares a scenario where a fast food company is willing to pay for a new high school gymnasium and other amenities in exchange for advertising and naming privileges. Next, students cluster by assignment into 10 special interest groups such as school administrators, student groups, coaches, local food merchants, and others to formulate an opinion on the proposal. The large group reconvenes and one student from each group shares their opinion of the proposal. Finally, the whole class votes on the motion. This exercise provides students the opportunity to view a contentious issue from multiple perspectives and actively discuss it with their peers. 


\section{Soul Food Dinner}

As a way to promote social engagement, the three authors coordinated a soul food dinner experience for all students enrolled in the section. Soul food was selected as a theme based on the common book choice for fall semester 2009, A Lesson before Dying by Ernest Gaines. Discussion revolved around the importance of food in helping to build community and as a way to explore family relationships (e.g., sociology perspectives). The dinner was held in the evening outside of scheduled class time, and all students were expected to participate.

\section{Individual Capstone}

All students complete an extensive individual research project using scholarly sources. This assignment asks students to: 1) select a food-related topic of interest and pose a question to be addressed (e.g., Why are organic foods not accessible to all individuals?); and 2) answer the question using at least two discipline perspectives (e.g., biology and sociology; law and political science) integrating library resources. Students meet individually with faculty for writing conferences and engage in peer editing. Many students visit the university writing center as well. They produce at least two drafts of this paper.

\section{Group Capstone}

The group capstone project involves the production of a public service announcement involving a topic related to food. Students work in small groups to brainstorm ideas, write a script, shoot, edit, and produce a video. The project requires students to: 1) work extensively on a team and hone interpersonal communication skills; and 2) produce and share a final product in the form of a YouTube video. All videos are shown publically at a college-wide showcase event at the end of the semester. All six FYE sections participate in the event.

\section{OUTCOMES: HOW DID THE STRATEGIES WORK?}

Overall, students' journal entries show a high degree of engagement and satisfaction with these strategies. One student wrote that the farmers' market assignment "gave me a perspective [on] local food. It was awesome to see the farmers all gathering and trying to make a living by selling what they have produced with their own sweat and time." With respect to the town hall meeting, a student found the activity important "because I was arguing my opinions in front of the whole class, and took part in a discussion in front of the whole class," something not always easy for students, especially first-year students, to feel comfortable doing in a large lecture setting. As for the Individual Capstone, one student commented that the assignment "went a long way [towards] developing me as a writer," helping the student to understand "how a college paper is written."

Students likewise found the group capstone project to be a significant activity in their learning and engagement in the course. For one, the project made the university "a smaller, more community-like place," while others saw gains that could extend to their lives beyond the academic world. "Working in a group of people that may not be your best friends can be tough," one student observed, "but it does happen often in the real world, especially in the field I plan on going into. This project gave me insight on what working in a group like that would feel like." Another student, looking to her future career goals, wrote that "In our world today there are little to no professions that require you to work entirely on your own. Skills [in] working with other people are vital to career success."

\section{APPLICATION}

The five strategies below were used in all FYE sections and shared among departmental faculty. Educators might consider implementing them into their own first-year programs.

\section{Integrate Traditional Collaborative Learning Activities into A Larger Lecture Class}

One strategy is to create small groups within the large group; then students assign representatives to report back to the large group. Barbara Gross Davis' Tools for Teaching (2009) is an invaluable resource for practical, classroom-based ideas. 


\section{Create Off-campus Experiential Activities}

Students repeatedly stated that these out-of-classroom opportunities (e.g., farmers' market visit for the food theme-based section) were most engaging and fostered social engagement with peers. Intentional integration of these experiential activities contributes to the overall learning experience, especially for first-year students (Lardner \& Malnarich, 2008). Utilizing community resources and exposing students to new experiences can stretch and challenge them in new ways. These experiential activities are comparable to what the Gestalt psychologist Fritz Perls termed safe emergencies; despite initial anxieties, no one gets hurt and most students benefit from the experience.

\section{Assign Students to Collaborative Groups to Create A Product or Project and Share Publicly}

All of the first-year students in CEHD participated in a college-wide showcase event at the end of the semester to share their work with others; it provided a sense of ownership of student work. In the food section, the YouTube video project allowed for a final product that represented their collaborative efforts as a group.

\section{Experiment with Team-taught, Multidisciplinary Instruction in the FYE}

This format provides students and faculty with the opportunity to critically explore and analyze key concepts around a theme from multiple lenses. Sharing the space in the large group allows students to observe and participate in multidisciplinary discussions.

\section{Engage in Ongoing Assessment and Evaluation}

Students were assigned numerous reflective writing assignments. This provided two outcomes: (a) students developed strong writing skills, and 2) faculty and staff were provided ongoing feedback about students' experiences. An effective FYE program is grounded in a culture of evidence.

\section{CONCLUSION}

The University of Minnesota-Twin Cities CEHD first-year inquiry program is a work in progress, and there are several revisions that are being considered for all sections based on feedback from faculty and students.

First, faculty members are discussing the option of integrating a service-learning component. This is a high impact educational practice and an important one for first-year students. One possibility for the food section is to require students to do service work for a local food shelf such as Second Harvest Heartland. Again, the questions remain: "How does this model work for 75-80 students who attend a big university in a large metro area?" "How many hours would students be expected to commit to in order to gain a worthwhile experience?" "How do we administer the service learning component?"

Second, departmental leaders are debating the most efficient and effective ways to sustain the current program. This model of three faculty members is complex in terms of long-range planning and resource allocation. How will we manage to sustain it in tight economic times amidst growing budget cuts and potential staffing changes (e.g., sabbatical leaves)? If we need to re-structure the course to a two faculty model, will the multidisciplinary nature of the experience for students and faculty members be lost? Ongoing communication within the department will be critical to success.

Third, faculty and staff are seeking out innovative ways to link course content with practical yet important information regarding student services (e.g., academic advising, career planning, and financial management skills). This integration requires careful planning and constant communication. How do you continue to integrate collegelevel content grounded in the disciplines with practical, first-year student management issues (e.g., locating campus resources, major and career exploration, and financial literacy skills among other topics)? 
Despite these challenges, faculty members look forward to generating new and innovative strategies to best serve the needs and issues of the college's first-year students. Intentional integration of high impact educational practices and educationally purposeful activities in both small and large group settings proves to be an effective strategy for this first-year experience program.

Note: Several key concepts of this draft were initially accepted for a brief by ESource of the National Resource Center for the First-Year Experience and Students in Transition, University of South Carolina. Copyright permissions have been granted.

\section{AUTHOR INFORMATION}

Michael Stebleton, PhD, is an Assistant Professor in the Department of Postsecondary Teaching Learning (PsTL) at the University of Minnesota-Twin Cities.

Murray Jensen, PhD, is an Associate Professor in PsTL at the University of Minnesota-Twin Cities.

Gary Peter, JD, MFA, is a Senior Teaching Specialist in PsTL at the University of Minnesota-Twin Cities.

\section{REFERENCES}

1. Brookfield, S. D. (1995). Becoming a critically reflective teacher. San Francisco: Jossey-Bass.

2. Davis, B. G. (2009). Tools for teaching (2 ${ }^{\text {nd }}$ ed.). San Francisco: Jossey Bass.

3. Harper, S. R., \& Quaye, S. J. (2009). Student engagement in higher education: Theoretical perspectives and practical approaches for diverse populations. New York: Routledge.

4. Hu, S., \& Kuh, G. D. (2002). Being (dis)engaged in educationally purposeful activities: The influences of student and institutional characteristics. Research in Higher Education, 43(5), 555-575.

5. Johnson, D., Johnson, R., \& Holubec, E. (1998). Cooperation in the classroom. Boston: Allyn and Bacon.

6. Kinzie, J., Gonyea, R., Kuh, G. D., Umbach, P., Blaich, C., \& Korkmaz, A. (2007). The relationship between gender and student engagement in college. Paper presented at the Association for the Study of Higher Education, Louisville, KY.

7. Kolb, D. (1984). Experiential learning: Experience as the source of learning and development. Englewood Cliffs, NJ: Prentice-Hall.

8. Kuh, G. D. (2009). What student affairs professionals need to know about student engagement. Journal of College Student Development, 50, 683-706.

9. Kuh, G. D. (2008). High-impact educational practices: What they are, who has access to them, and why they matter. Washington, DC: Association of American Colleges and Universities.

10. Kuh, G. D., Kinzie, J., Schuh, J. H., \& Whitt, E. J. (2005). Student success in college: Creating conditions that matter. San Francisco: Jossey-Bass.

11. Lardner, E., \& Malnarich, G. (2008). A new era in learning: Why the pedagogy of intentional integration matters. Change, 40(4), 30-37.

12. Oldenburg, R. (1999). The great good place: Cafes, coffee shops, bookstores, bars, hair salons and other hangouts at the heart of community. New York: Marlowe \& Company.

13. Pascarella, E. T., \& Terenzini, P. T. (2005). How college affects students: A third decade of research (Vol. 2). San Francisco: Jossey-Bass.

14. Tiemann, T. K. (2008). Grower-only farmers' markets: Public spaces and third places. Journal of Popular Culture, 41, 467-487. doi: 10.1111/j.1540-5931.2008.00531.x.

15. Tinto, V. (1993). Leaving college: Rethinking the causes and cures of student attrition ( ${ }^{\text {nd }}$ ed.). Chicago: University of Chicago Press.

16. Wolf-Wendel, L., Ward, K., \& Kinzie, J. (2009). A tangled web of terms: The overlap and unique contribution of involvement, engagement, and integration to understanding college student success. Journal of College Student Development, 50, 407-428. 